\title{
Role Of Women In Stand-Up Comedy Indonesia
}

\author{
${ }^{1}$ Lambok Hermanto Sihombing, ${ }^{2}$ Kevin Marcellian, ${ }^{3}$ Okky Abrina T, ${ }^{4}$ Yohanna Piay \\ 1, 2, 3,4 Public Relations of Communication Studies, President University \\ Email Korespondensi: lambok@president.ac.id
}

\begin{tabular}{l}
\hline \hline Article Info \\
Article history: \\
Article Received: June 222021 \\
Publication: July 102021 \\
\\
\hline
\end{tabular}

Keywords:

Feminism, Stand-Up Comedy, Women

Corresponding Author:

\section{Lambok Hermanto Sihombing}

Public Relations of Communication Studies,

President University

Emaili:lambok@president.ac.id

\section{INTRODUCTION}

\subsection{The meaning of stand-up comedy and the entry of stand-up comedy into Indonesia}

Stand-Up Comedy is a modern comedy art, the comedians or comics perform their performances in front of the audience by bringing jokes, the way they speak directly and face the audience's reactions. comedian appearances are also usually recorded and broadcast on television, the internet but the main atmosphere is found during the Live Show (live / live show). Various ways of presenting performances for Comics, for stand-up comedies that use property (tools), music, magic acts etc. are their ways to attract shows but it is a "development" from stand-up comedy which generally does not use equipment (Papana 2016).

The beginning of the history of the birth of Stand-up Comedy began around the 1800s in America, when it was still a theater performance and one of them that was ever recorded was the one called The Minstrel Show, hosted by Thomas Dartmouth "Daddy" Rice. Even though the jokes are still very simple jokes / humor, this event at that time still contained racism.

From the history that Stand-Up Comedy has gone through in Indonesia, there are several things that have not been known from the birth of stand-up comedy into an Indonesian stand-up comedy community. While the world of Indonesian cinema made Indonesians look for alternative entertainment, stand-up comedy programs appeared on several television stations that formed the Indonesian stand-up comedy community. The idea 
for the event was raised by Ernest Prakasa, then it was formed very large by Panjdi Pragiwaksono, Raditya Dika and Ernest, Ryan Adriandhy and Isman HS. (GITA 2019)

Different views according to (Papana 2016) Stand-Up Comedy in Indonesia has developed very rapidly, since the 2000s and then the implementation started from Comedy Cafe Indonesia in 2011. From then on, Stand-Up Comedy exploded and was broadcast on Indonesian television in the form of shows and competitions. There are already dozens of Stand-Up Comedy communities throughout Indonesia, from Aceh, Lampung, Manado to Timika in Papua, Kupang, Samarinda, Bali, Cianjur, Depok, and others.

\subsection{The development of Stand-up Comedy in Indonesia throughout the years}

Just with followers on twitter, they challenge themselves to hold an event which they named "\#Standupnite". The event was held on July 13, 2011 at the Comedy cafe, Jakarta. Even though just doing advertisements through Twitter, the public's excitement for this new alternative entertainment can be said to be extraordinary event. Many superstars were attending in this event, from national level celebrities to celebrities who were only famous on twitter or they called themselves "celebtweet". From this event, July 13 was chosen as the date for the establishment of the Stand Up Indo community.

After holding the "\#standupnite" event, they were enthusiastic about making a continuation of the event called "\#standupnite2". This event was held at Bober Bistro, Bandung on 12 August 2011. The event was attended by a few finalists from Stand-up comedy Indonesia. At the event, Raditya Dika also participated in making this event \#standupnite2 exciting.

Still in August, to be exact date August 17, 2011 at Rolling Stones Cafe Indonesia, Stand Up Indo charity event entitled "\#laugh4love". We can see that stand-up comedy in Indonesia is not only for entertainment purposes, but they also use their abilities or professions to raise charity.

Because of the successful of the event, many people who previously had professions outside of stand-up comedy have finally joined the world of stand-up comedy. Like Asmara Letizia (Miund) and Farhan who were already known as radio announcers, Rene Suhardono a career coach and Soleh Solihun a funny journalist.

After the success of the three events (\#standupnite, \#standupnite2, and \#laugh4love) finally stand up indo made their first paid event which was still at the Rolling Stones Cafe Indonesia, on August 24, 2011, this event managed to bring in more than 900 visitors.

That is how the Stand Up Indo community was established, which up until today keeps on creating abilities for professional comics from all over Indonesia. Up to this day, there have been many stand-up comedy communities that already established throughout Indonesia from Sabang to Merauke, the number is estimated to have reached at more than hundreds. The people group / community begins from the area/city level to go into institutions like organizations, colleges and schools. Because Stand-Up comedy has captivated the hearts of Indonesian teenagers, Kompas TV held a standup comedy competition calles Stand Up Comedy Indonesia (SUCI), then Kompas TV launched a new innovation and organized a stand-up comedy competition between communities which called "Liga Komunitas Stand Up (LKS). On January 2 2015, the LKS grand final was held and won by the Indo Medan stand-up as the $1^{\text {st }}$ winner, $2^{\text {nd }}$ place was Indo West Jakarta stand-up, and the $3^{\text {rd }}$ place was Indo Bogor stand-up and for the $4^{\text {th }}$ place is the Indo BTS stand-up.

\subsection{Women in The Stand Up Comedy Indonesia}

So far, women have only been used as objects of exploitation from various aspects (economy, health, politics, biology and some). In the Indonesian public sphere, women are still discriminated against (Suhendra, 2012). However, emancipation is still used in Indonesia and there are many campaigns regarding women in struggle in various aspects including in the world of Stand Up Comedy (M. Reza Sulaiman, 2019). It is rare to see and watch women in a stand-up comedy show because in Indonesia there are still 
few enthusiasts for the role of women in stand-up comedy in the sense that it is not because women are not proper, only that society looks more at the role of men in stand-up comedy. Currently, several women are trying to make a comedy as well as voice the problems of women who still have a minimal role in Indonesia.

Sakdiyah Ma'ruf is an Indonesian stand-up comedian. This woman, known as Diyah, is the first female standup comedian in Indonesia to wear a hijab. Diyah is well-known for her jokes about Islam, which she uses to combat Islamic extremism in Indonesia.

She spends her free time performing stand-up comedy. Diyah has appeared on stage with other comedians. Producers also asked her to censor her own content during many TV appearances, arguing that it is too 1philosophical, 2theoretical, and 3laden with messages. Still, in a community where women were openly caned for being victims of crime, Diyah felt compelled to survive.

Kiky Saputri is one of the SUCA 4 participants \& a finalist in the stand-up comedy competition "Criticism of the DPR". She is also known as one of the comics who often roasts the Government. The figures she has roasted is including Fadli Zon, Susi Pudjiastuti, Sandiaga Uno, Hanif Dhakiri, and Retno Marsudi. Kiky Saputri proves that female comics also look tough, smart, and deadly as well as male comics.

Arafah Rianti, who is basically innocent and shy, was curious because she rarely talked to many people, and wanted to try to express what she felt to the people around her, so she choose stand-up comedy. Arafah's achievement in Stand Up Comedy is phenomenal because at a young age and not much experience, Arafah has shown that she can achieve the highest level of achievement in stand-up comedy.

Mega Salsabila is a participant of Stand Up Comedy Academy (SUCA) 4. She is a widow who always uses her life story as a widow for comedy material. Mega is indeed a person who likes to tell stories about her life, but the people around who hear her stories are even entertained. That is the root of his interest in stand-up comedy.

Therefore, by seeing how fast the Stand-up Comedy grows in Indonesia, the researcher wants to analyze one issue that relates to this common topic by asking:

1. how is the role of women in stand-up comedy Indonesia?

\section{LITERATURE REVIEW}

\subsection{Popular Culture Theory}

Many people within this particular culture which were exposed to the prevalent aspects of pop culture are familiar with "popular" culture. People are more likely to see pop culture as a fun and trivial thing, according to (Trier-Bieniek, 2014) and as a result, they may neglect to interrogate messages in pop culture and how they affect society.

Popular culture is a dynamic which is always moving around. Popular culture is created or modified in every social transmission, instead of just being passed down from generation to generation (Salmon, 2012)

"Popular" culture is known to the majority of the masses of that particular society, exposed to the dominant aspects of pop culture in the same context. (Trier-Bieniek, 2014) proposed that people were more likely to see pop culture as a fun and frivolous thing, and because of that, people may not be able to confront pop culture messages and how it affects the society.

\subsection{Television Theory}

Television is a method of broadcasting that captures pictorial broadcasts in the form of audio-visual and video broadcasting. Since the viewers are far from the TV studio, this word comes from Greek, namely tele (far) and vision (to see). It literally mean s "to see far away." 255) (Ilham, 2010)

Meanwhile, according to (Adi, 2010) television is also a visual and even a communication media (audio-visual), in which people not only see but also hear or ingest the narrative of the images seen on television. Film, as an industry, is a part of a society's 
economic production, and it must be viewed in context with other objects. Films are an integral part of the mechanism used by individuals and groups to send and receive messages as correspondence (communication) (send and receive messages). (Ibrahim, 2011)

\subsection{Media Pop Culture}

Pop culture circulates throughout or throughout contemporary society. The media now fuse popular culture with the world of today's culture such as those who better understand journal articles and the various problems presented, connect fast, differentiate relevant TV from the anecdotes of simple people, so that today so much people discuss the popular culture, which enters the world of media as well. The extent to which pop culture fits into the classroom and the scope is also demonstrated in recent research in Canada.

Mainly Taiwan and Hong Kong are students. The majority of local students grew up in the same area and went to the same elementary school. They have a wide pool of common knowledge and cultural experiences. This excerpt comes from the classroom article on pop culture and other references from the media. Students co-create and redefine their nonacademic and academic texts. According to his research, students and their families listen to local news channels (radio, television) and subscribe to daily journals and then there are different pop culture worlds.

They listen to radio, youthful pop music is included and TV's role in pop cultural activities is meant, They watch a re-recorded television show with them, such as The Simpsons, which is then seen presented in front of the class. Media and pop culture had a link to daily life at first (Duff, 2019).

\subsection{Feminism}

In the book Encyclopedia of Feminism, written by Lisa Tuttle in 1986, feminism in English feminism, which comes from Latin femina (woman), literally meaning "having the qualities of females". Term it is aimed at theories about sexual equality and movement women's rights, replaced womanism in the 1980s (R.Valentina, 20004).

\subsection{Feminism in the mass media}

Since the birth of feminism, mass media (films, advertisements, talk shows) have functioned as a means of struggle this movement. The mass media is believed to be used as an ideological tool for against stereotyping the image of women by men. In particular, as a tool to increase respect for women who are positioned inferiorly (Nelmes, 2017).

\section{METHOD}

This research applies Stand Up Comedy analysis to Pop-Culture so that it enters the television world.

The data source used is taken from several articles searched through Google Scholar. We use these elements because they are easy to obtain and understand for analysis searches to be made.

The first step is to perform data selection and look for elements of some articles that we get such as paying attention to the title, year of manufacture, research variables whether or not they are appropriate for the articles we analyze, the second step data classification from several articles that we took, some data considered that Stand Up Comedy has become a creative industry event that is increasingly enthusiasts by Indonesians of all ages, for the third step Data analysis that we use is that we analyze Stand Up Comedy on creative industries and in the television world and the final step of the research, we can conclude that Stand Up Comedy in Indonesia is very much in demand with evidence of the many enthusiasts of Stand Up Comedy programs on television, such as SUCI. this "Stand Up Comedy Indonesia" program also brings back the comedy show program that has been around for a long time. That is how Stand Up Comedy affect the creative industry in Indonesia. 


\section{DISCUSSION}

\subsection{Arafah Rianti}

The 2nd winner in the SUCA 2 event, Arafah is a female Komika who wears a hijab and is known as a comic with a unique voice, beautiful and innocent with absurd material presented. Having been underestimated by the public because of the unique voice arafah at SUCA 2 and her absurd material that made the public think weird, arafah never gave up on her journey as a comedian she continued to practice until she was able to compete with other contestants who had superior experience further from her. Arafah proved her to be a successful female comic so she got an offer from the famous comic, Ernest. Some of the films that Ernest offered to arafah were successful in Indonesian society, such as "Cek Toko Sebelah ". In her career success, of course arafah has experienced a decline in his appearance but with the enthusiasm that arafah has, she made it into the grand final with Aci Resti and Hernawan Yoga to become runner-up 2. on the other hand, there is a story about the mother's blessing from arafah, apparently arafah was not approved by her mother. As a woman, arafah has to go home at night because Stand Up Comedy likes to go home at night, so in her view, women playing and coming home at night is not good. But after arafah got the results from Stand Up Comedy, her mother finally gave her blessing because it was not in vain to come home at night.

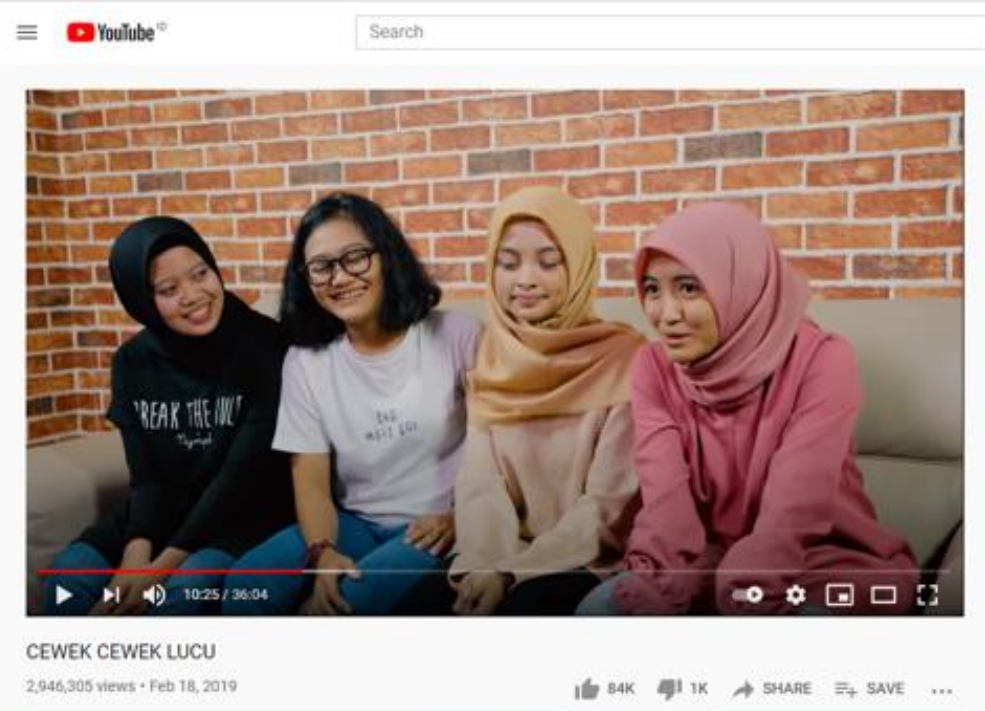

From the scene (youtube) of Raditya Dika, radit brings the female comic as a champion of SUCA 1-2. Radit interviewed them about their period after becoming champions in Suca and plunging into the world of Stand Up Comedy. changes that happened to them in the world of Stand Up Comedy. for Arafah, musdalifah, neneng, and aci, if there was no standup comedy, maybe their fate would not be better as it is now. Arafah can buy a car from stand-up comedy results and be summoned to any event, neneng and aci often play movies, musdalifah can own a house unlike before who slept only on the floor. Their female comics can also convey material that can be their opportunity to voice women's points of view on the comedy stage.

\subsection{Kiky Saputri}

The name Kiky herself began to be known among comedians since she was active in the community and became increasingly popular after participating in a stand-up comedy competition on a national private television station. In this competition, she managed to rank in the top eight, until then she often appeared in various programs that aired, both live (live) and off air. 


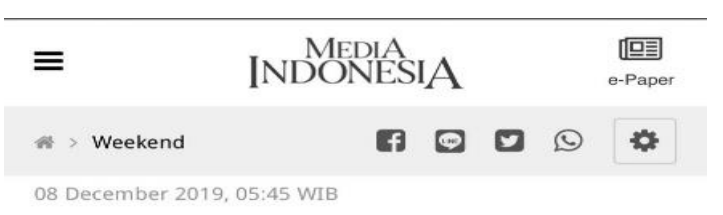

\section{Kiky Saputri Percaya Diri dengan Stand Up Comedy \\ (Gas/H-1) | Weekend}

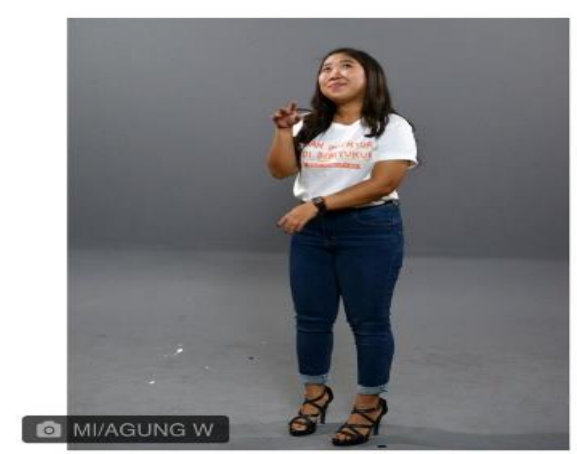

Kiky also participated in the DPR Criticism stand up comedy competition and won third place in the event. This is where the name Kiky Saputri began to skyrocket since she roasted politician Fadly Zon and several other state officials.

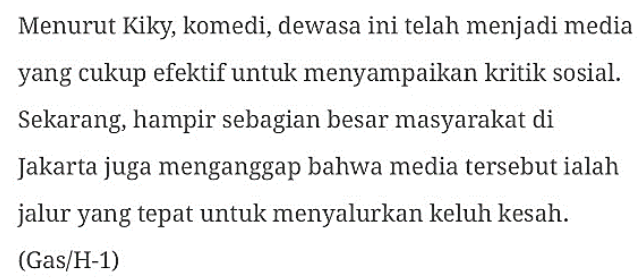

In March 2019, she played the role of Romlah in ANTV program 'Masjid yang Dirindukan'. In December 2019, she made her big screen debut with 'Imperfect: Karier, Cinta \& Timbangan' where she played Neti. After she started her career as a stand-up comedian and penetrated into film, she received 3 nominations for: selected newcomer actress, best newcomer actor, and favorite newcomer actor.

\subsection{Mega Salsabila}

Mega Salsabila is a finalist of Stand Up Comedy Academy (SUCA) 4. She is a widow who always uses her life story as a widow for comedy material. Mega is indeed a person who likes to tell stories about her life, but the people around who hear her stories are even entertained. That is the root of his interest in stand up comedy.

\section{Berawal Dari Gemar Cerita, Mega si Janda Akhirnya Sampai di Panggung SUCA 4}

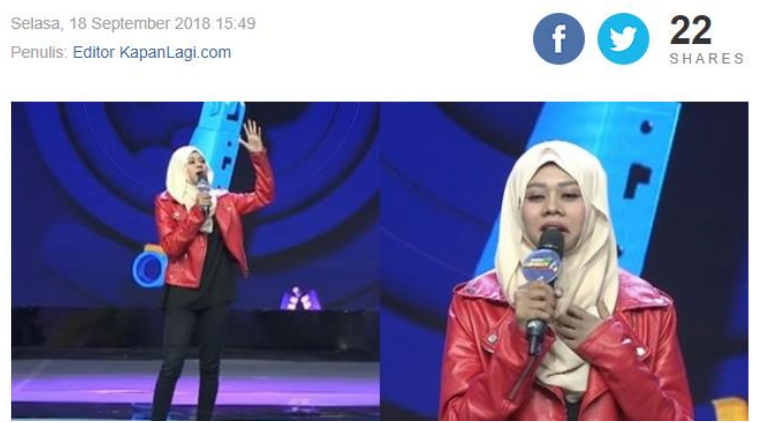

The first time she wants to join the Stand Up Comedy community is because she wanted to brake another comic's statement about "widow" by doing a stand up using her widow life story for make everyone laugh. She admitted that she fell in love with stand-up comedy because she watched one of a stand-up comedian named Neneng. And I quote "So when I 
wanted to stand up for the first time, I saw a SUCA 3 comic called Neneng. She has material, 'Neneng's friends in the village have already married, they have become widows, but someone can grab someone's husband again'. Then I feel that next year I have to be there, to argue with that, "she said.

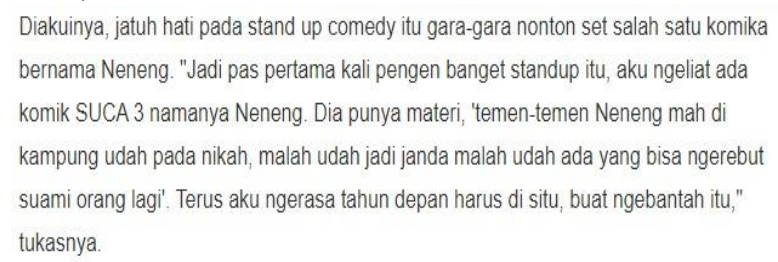

After having the determination to refute Neneng's statement, he then joined the Stand Up community and started participating in competitions. Now it's been years since she joined the Tangerang stand-up community. Qualifying for SUCA 4 to enter the top 24, of course because of the support of her fans and those closest to her too.

Sakdiyah Ma'ruf is an Indonesian stand-up comedian. She is known for addressing Islamic extremism in Indonesia within her comedic routines.

Since around 2009, Ma'ruf has worked full-time as a professional interpreter and translator. In her spare time, she performs comedy. She has appeared on a private television channel, performed at local venues in Jakarta, and taken part in a stage show with fellow comedians. During some of her appearances on TV, producers have asked her to censor her own jokes, telling her that she is 'too conceptual, theoretical, laden with message. But she feel compelled to persevere, living in a society where women are publicly caned for being the victims of gang rape.

$$
\begin{aligned}
& \text { she works a vibrant Indonesian club scene } \\
& \text { and performs on TV. Producers have asked } \\
& \text { her to censor her own jokes, telling her that } \\
& \text { she is "too conceptual, theoretical, laden } \\
& \text { with message," but the stakes are too high } \\
& \text { for Sakdiyah to shut up. Just days ago, a } \\
& \text { young Indonesian widow from the } \\
& \text { neighboring island of Sumatra was } \\
& \text { sentenced to public caning for breaking } \\
& \text { Sharia law. The widow's crime? Surviving a } \\
& \text { gang rape. }
\end{aligned}
$$

Hans David Tampubolon wrote in The Jakarta Post in November 2014 that, the otherwise lame and boring stand-up comedy scene in Indonesia, Ma'ruf has started what could be considered a revolution and has raised eyebrows with her stage appearances because she likes to blatantly address highly controversial issues that are usually avoided by 'popular' comics for the sake of keeping their faces on your television screens. Tampubolon states that given her distinctive look and growing popularity, Ma'ruf could have easily become a major mainstream comedic star on TV, but because of constant demands by TV producers that she censors herself, she opted to perform live instead, delivering her uncensored messages to preserve her art. She has said that for her, being a comic is not about fame or money but rather about giving her audience an unforgettable experience and making them think about societal issues and those affecting them personally, even after the curtain goes down. 


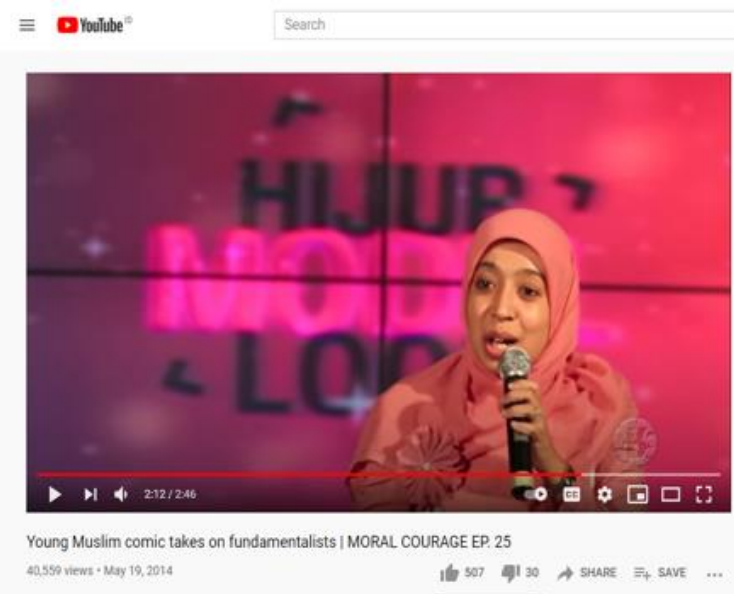

Among her influences she has cited Sarah Silverman, Tina Fey, Margaret Cho, Roseanne, Ellen, Kathy Griffin, Robin Williams, Stephen Colbert, Chris Rock, Ricky Gervais, and Jerry Seinfeld. Her favorite comic is Louis C.K. She has been described as having the cheerfulness of Williams, the bitterness of Louis and just like Cosby, she never uses swear words or profanity in delivering her messages. Much of her comedy is about Islamic extremism; she has complained for nearly a decade after the introduction of democracy, Indonesia has witnessed a significant growth of turban-wearing, beard-growing, loudscreaming Muslims encouraging the Islam that does not tolerate women and minorities to speak up. She has said that despite her upbringing, she enjoys American sitcoms more than televised da'wah. I don't speak Arabic like most of my cousins, and I firmly think that ethnic purity that my community claims is nothing but hallucination as we are all actually mixed blood having been living in Indonesia since the Colonial Era. In fact, it may also hurt our religiosity as I believe Allah created us free and equal and will not judge us, except for our obedience and devotion to Him. Still, she wears a veil because she considers it liberating: it counters impossible beauty standards. It asserts ownership over her own body. Her use of the veil is also a way she resists the gravitational pull of the fashion industry, allowing her to focus on issues of justice, violence and equality.

\section{CONCLUSION}

Stand-Up Comedy is a modern comedy art, the comedians or comics perform their performances in front of the audience by bringing jokes, the way they speak directly and face the audience's reactions. Stand-Up Comedy appearances are usually broadcast on television. Women today are very free to be creative in any field, It is rare to see and watch women in a stand-up comedy show because in Indonesia there are still few enthusiasts for the role of women in stand-up comedy in the sense that it is not because women are not proper, only that society looks more at the role of men in stand-up comedy. Currently, several women are trying to make a comedy as well as voice the problems of women who still have a minimal role in Indonesia. But 4 of many women comics such as Sakdiyah Ma'ruf, Kiky Saputri, Arafah Rianti, and Mega Salsabila really have an amazing career in stand-up comedy world. Those 4 women are the example of hardworking people that really determine their success, break the female stereotype, and help the Stand Up Comedy Indonesia really stand out in the creative media industry in Indonesia.

\section{REFERENCES}

Adi, B. (2010). Jurnalistik Televisi. Yogyakarta: Graha Ilmu.

Anjari, M. W. (2015). KANDUNGAN KRITIK SOSIAL DALAM STAND UP COMEDY. 121.

Astuti, S. P. (2016). PENGARUH PENERAPAN MEDIA CAI (COMPUTER ASSISTED INSTRUCTION) TERHADAP PENINGKATAN KEMAMPUAN MENGENAL 
ALFABET DI TK PL BERNARDUS SEMARANG (STUDI KASUS: TK PL BERNARDUS TAHUN 2015) (Doctoral dissertation, Universitas Negeri Semarang).

Badara, A. (2018). Stand-up Comedy Humor Discourse in Local Perspective in Indonesia. IJALEL, 7.

Duff, P. (2019). Pop Culture and ESL Students: Intertextuality, Identity, and Participation in Classroom. International Literacy Association, 482-487.

Hakim, N. I. (2018). Hakim, Nur Ilahi. "Kehadiran Stand Up Comedy Indonesia." 2018.

Ibrahim, I. S. (2011). Kritik Budaya Komunikasi: Budaya, Media dan Gaya. Yogyakarta : Jalasutra.

Idha Nurhamidah, P. P. (2020). ANALISIS WACANA KRITIS PADA STAND UP COMEDY INDONESIA. Haluan Sastra Budaya, 2.

Ilham, Z. (2010). Two-step supercritical dimethyl carbonate method for biodiesel production from Jatropha curcas oil. Bioresource Technology, 2735-2740.

Krissandy. (2014). Unsur- unsur film. Jakarta : UIN Syarif Hidayatullah.

Maulana, A. F. (2018). LKP: Proses Pasca Kerja Jawa Post Media Televisi Surabaya Provinsi Jawa Timur (Doctoral dissertation, Institut Bisnis dan Informatika Stikom Surabaya).

Maulana, A. F. (2018). LKP: Proses Pasca Kerja Jawa Post Media Televisi Surabaya Provinsi Jawa Timur (Doctoral dissertation, Institut Bisnis dan Informatika Stikom Surabaya)

Salmon, M. L. (2012). Human Nature and Pop Culture. Review of General Psychology, 102.

Susilana, R. R. (2008). Media pembelajaran: hakikat, pengembangan, pemanfaatan, dan penilaian. Bandung : CV wacana prima.

Trier-Bieniek, P. L. (2014). Introduction to Gender \& Pop Culture. Gender \& Pop Culture, 125. 